\title{
CHANGES IN FOREIGN AND MODERN CULTURE IN THE 21ST CENTURY WHICH DRIVERS CULTURE IN EAST JAVA SEEN FROM A HISTORICAL PERSPECTIVE
}

\author{
Sangwa Cahyo Utomo ${ }^{1}$, Moses Glorino Rumambo Pandin ${ }^{2}$ \\ ${ }^{12}$ Faculty of Humanities, Airlangga University \\ sangwa.cahyo.utomo-2020@,fib.unair.ac.id; moses.glorino@,fib.unair.ac.id
}

\begin{abstract}
In modern times like today, technology and science are developing very fast. This has resulted in a condition known as globalization. This era has had a significant impact on every country globally, including in Indonesia, such as the spread of culture is solid. This flow has many benefits and advantages. However, this globalization can also have a negative impact. One of them is the erosion of native Indonesian culture compared to foreign cultures. Therefore, this research to find the origin, causes, and impacts of the influx of cultural globalization on the current culture of East Java because it is the province of origin of the researchers. Here the researchers asks about the impact of this modern culture and how influential culture is to the people of East Java. The method used by the researchers in making this paper is Literature Review using qualitative descriptive writing with quantitative data. The researchers findings as material in this paper amounted to 24 materials with the provisions of 20 journal article materials, 2 article materials online provided that they were published in the last three years, and 2 E-books for methods on this paper. This study's boundaries are a modern culture that the researchers takes about western culture (western) and South Korean culture (Hallyu). In addition, this study only discusses cultures originating in East Java, such as Javanese.
\end{abstract}

Keywords: Culture, Globalization, East Java, Westernization, Hallyu 


\section{INTRODUCTION}

In the present or the 21 st century, the development of culture is very massive. All information and activities with this cultural flavor can be accessed very quickly and can be done directly. This culture has permanently changed from time to time; this change occurs because society wants cultural change and change to occur very rapidly, namely because globalization enters Indonesian culture. Globalization has entered uncontrollably into the national culture, which is the incarnation of local culture in every region from Sabang to Merauke (Tobroni: 2012: 123) (19).

The culture that is currently developing is called modern culture. Modern culture is meant here is the influence of European and American culture. Modern culture is characterized by strong scientific and economic values, while religious and artistic values are increasingly showing weaknesses, as seen in the religious and artistic crises in Europe and America today. Countries that adhere to democracy highly uphold the value of solidarity, while in totalitarian countries like Russia, the strongest is the value of power (16).

The original culture of Indonesia, which should have become a wealth and unifying tool for the nation, is now beginning to be forgotten and abandoned because many of the younger generations are reluctant to study and keep it. They think that the original culture of Indonesia is very ancient and does not keep up with the times. They prefer to study the foreign culture that entered Indonesia, even though it does not follow national identity (15).

The foreign culture that enters Indonesia can be a factor causing this cultural crisis as a negative impact of globalization, as mentioned above. Two cultures that have developed rapidly recently are Western (Western) culture (8) and South Korean (Hallyu) culture (1) (4). These two cultures have the greatest influence on the world of entertainment, such as music and film/drama. In addition, other things go with these two influences, such as culinary, habitual behavior, and fashion. Globalization is a driving reason for the emergence of the Korean wave, according to (Sara M. Hamilton, 2008) (4).

The role of history as a paradigm today is very much needed in this time, especially in culture. However, so far, the public assumes that studying history is boring, full of memorizing years, significant figures, the role of students passively accepting, and as something that cannot be criticized (historical term: straightening). This understanding is very harmful to history itself, for example is .cultural history. The monotonous, one-way, uncreative way of teaching history has further strengthened this stigma. If things like this continue to be done, it will create a millennial generation who are considered to be without history and culture. Culture and history cannot be separated and are related to another one (20). 
With the negative impacts that have been described above, it is necessary to change again in the preservation of Indonesian culture, especially in the East Java region, so that it is not just a memory. East Java is the largest province on Java island; this province has 29 districts and nine cities in which there is ethnic and cultural diversity (6). In its implementation, every level of society, especially the millennial generation, is needed to maintain this culture. This role can be started from small things. One of them is developing national insight and strengthening historical knowledge as the root of culture first. One other form is the formation of this paper article.

This paper article aims to understand the culture in general, Western culture, and South Korean culture. Then, it is proven by the impact of this culture in modern times with the current globalization. Then, the importance of solutions that must be carried out from the negative impacts caused. The question asked by the author in making this first article is how the understanding of culture as a whole as well as the impact it has on the current situation. Then, the second question is the relationship between history and culture, especially for cultures from East Java. Then, the third question is how important it is to keep up the culture between foreign and modern cultures that are overgrowing.

\section{METHOD}

The author in this paper uses a literature review. A literature review is a basic review used by the author in a later study based on discussion topics carried out in detail and periodically. The most important thing from this literature review is the content of the literature. The content is used as a source and reference for the author to work on the paper. The content is processed and then compared. With this literature review, the paper can prove its validity and correctness.

The method used by the researchers in this paper is a literature study. This method is used to find sources of data related to culture and globalization. book "Library Research Methods" on page 3, literature study is a series of activities related to methods of collecting data, reading, and recording research materials. Then on pages 12 and 16 explain that the literature study consists of 2 types, namely:

1. Literature study which means the researcher collects some data from journals

2. Other sources, one of which is from Internet searching which means the researcher looks for data from trusted website (24) 
In this paper, the researcher uses three types of data, namely journal articles, websites, and e-books. For journal articles total 20 journals, researchers got it through Google Scholar. For other sources obtained from official websites. Like the site source No. 22 about the first kingdom in East Java taken from the Historia.id website. The use of these data sources is related to the discussion, namely the influence of modern culture as the impact of globalization on East Javanese culture in the 21 st century. Then, journal articles are the main reference of this research. The journal article has explanations from several people who have conducted previous research. So, the capacity of the journal as a reference can be trusted to get better results.

The data analysis technique is done by looking for data first in this case about culture and globalization. Then, sort out which part is needed. When finished, then the data is put together to form this article. Then, after becoming an article paper, the results are made into sentences and tables. the data analysis technique is divided into three stages, namely:

1. Data reduction, which means that researchers carry out a process of selecting and centralizing data.

2. Presentation of data which means the researcher presents the data that has been reduced in the form of a brief description or table.

3. Drawing conclusions which means the researcher draws conclusions from the data that has been presented in the form of sentences. (23)

Having previously explained the stages in making research, of course there is a process for making the research. The process is considered as the application step of the earlier stages, in this paper the researchers carried out various processes.

The first step is to find and collect data. The researchers took various data from various places such as journal articles, websites, and e-books. The data is then collected according to what will be discussed by the researcher, namely about the influence of foreign cultures on East Javanese culture as a result of globalization. Once collected, the data will be selected which part will be included in this paper because not all the materials in the data are used. Then, the proper data is connected with the words of the researcher so that it becomes a good paper 
article. After the discussion, conclusions and benefits can be drawn from the discussion of the article.

\section{RESULTS}

From this research, researchers obtained 20 journal articles with coverage from 20192021. In addition, to strengthen the existence of this research, the author uses two trusted official websites. Both sites come from the jybmedia and historia websites. For journals, the authors get them from google scholar and each journal has a relationship with this research. Of the twenty-two articles found by researchers, 12 journals discuss culture, 3 journals discuss examples of cultural preservation, 4 discuss history, 2 journals discuss globalization, and 1 journal discuss nationality. In addition to using journal articles, researchers used 2 E-Books that discussed the methods in research. Both books have 2008 and 2019 publication years.

In this research, the authors found different results that will be described. Begins with understanding of culture from various experts. In this section, it is the definition of culture according to Soekmono (3). Then in this journal is the meaning of Koentjaraningrat (5). Furthermore, this section explains the meaning of Lowie (12). Especially in this section, the writer takes the classification of cultural forms according to Koentjaraningrat (16). This section also discusses the notion of culture in general (20). Then an explanation of the understanding of Westernization as a whole (8). Continuing from Westernization, researchers took data from the journal Hallyu (4), which discusses Westernization. Then, it further explained the meaning of Hallyu (South Korean Cultural Wave) (1) in general and the beginning of the emergence of Hallyu in Indonesia. Continuing from the Hallyu earlier, it was also explained about the development of the culture Hallyu (4). The following section discusses the notion of native East Java culture with various examples (21). This section also explains specifically about native musical instruments from East Java (6).

Then, the next section discusses the early history of East Javanese culture from prehistoric times or the beginning of the people who inhabited the East Java region, namely the Javanese Tribe (18). Then explained about the first kingdom in East Java, namely the Kingdom of Kanjuruhan (22). After that, it explains the history of the entry of culture during the Western Imperialism era called colonialism (2). This section also explains examples of clothing at that time in Java (10). 
After discussing culture, a general definition of globalization is explained (17). From this understanding, the key to globalization is discussed (11). In addition to the meaning and keys of globalization, the positive and negative impacts of globalization are also explained (13). The following section discusses the positive and negative impacts of a culture of Westernization (8). Then, it also explains the positive and negative impacts of South Korean /culture Hallyu (4).

In the next section, it is discussed how vital culture is to the nation, and one of the most effective ways that every Indonesian citizen must have is the importance of learning history, especially the cultural history of their respective regions, for example, East Javanese citizens must be able to know East Java culture at least). Furthermore, a data index of cultural growth in Indonesia was given in 2018 with a comparison of East Java as the key (12). Then, it explained the purpose and importance of cultural preservation (15). Furthermore, it is explained about the steps to keep Indonesian culture and can also be applied in East Java, Indonesia's provinces (19).

This section describes three examples of cultural preservation in East Java. First, it explains understanding and reading Javanese characters in Malang, East Java (7). Second, discussed the Tunggulwulung Cultural School in Malang City, East Java (11). Third, it is explained about getting used to Javanese (14).

\section{DISCUSSION}

\section{A. Culture}

\section{Definition of Culture}

Culture is the result of thoughts, values, which encompass all human actions in life. The scope of culture is extensive, so combining the word "Art Culture" in one phrase narrows the scope of culture itself. Art itself is part of the culture, as is language, religion, religious system, social system, a system of life adopted by a particular society (20). When viewed from the English word, culture comes from the Latin word cholera, which means to process or work, which then develops into the word culture, defined as human power and effort to change nature.

"Culture is the power of virtue in the form of creativity, intention, and taste. Virtue is defined as things related to the human mind which is a radiance of virtue and power to all that is thought, felt, and contemplated, and then practiced in the form of a force that produces life. Culture is the result of creation, intention, and taste, meaning that which processes or works to 
affect the level of knowledge, a system of ideas or ideas contained in the human mind, in everyday life, is abstract. While other manifestations of culture are objects created by humans as cultured beings, in the form of behavior and objects that are real, all of which are intended to help humans live in society. ". (Koentjaraningrat, 1990) (5).

According to another sense, culture is the heritage of the ancestors of civilization with distinctive characteristics and special symbols with different thoughts. Humans are creatures politicon zoon meaning animals that live in a society so that the culture can be passed on a horizontal line to the people around, so it is not just passed on vertically (blood lineage) (Soekmono, 1973) (3).

According to Lowie (1937), culture is everything that an individual obtains from society, including customs, prevailing norms, beliefs, and skills acquired not from their creativity but a legacy of the past obtained through formal education and education. Informal (12).

Koentjaraningrat $(1980 ; 186)$ classifies cultural forms into three parts.

1) The existence of culture as a complex of ideas, thoughts, values, norms, rules, etc.

2) The form of culture is a complex of activities and patterned actions of humans in society.

3) The existence of culture as objects of human work (16).

\section{Definition of Western Culture}

Westernization comes from the word western, which means west. Westernization means the process of Westernization, acquisition, or imitation of western culture. Westernization is when people in eastern countries adopt a Western culture in various fields such as industry, technology, law, politics, economics, lifestyle, dress code, language style, alphabet, religion, philosophy, and values. According to Samuel P. Huntington, Westernization is a process in society that follows all forms of western lifestyles. According to Koentjaraningrat, the meaning of Westernization is imitating the lifestyle of western people that is done by society excessively in the form of lifestyle, habits, social style, and so on (8). According to Soerjono Soekanto, the notion of Westernization is a life process that prioritizes industrialization and the capitalist economic system so that his life imitates or tries to be the same as the life of people in Western countries (8). 
This Western culture can be associated with popular culture in this world. Thus, initially, the study of popular culture (pop culture) could not be separated from the United States' role in producing and disseminating popular culture. The country has planted powerful roots in the popular culture industry, among others through Music Television (MTV), McDonald's, Hollywood, the animation industry (such as Walt Disney, Looney Tunes, etc.), and other products such as Levi's jeans, Apple iPhones, Marlboro cigarettes, Coca-Cola soft drinks, and Hollywood movies, by utilizing the desired image (Roll, 2020) (1).

\section{Understanding Korean Culture / Hallyu}

South Korea is one of the most prosperous countries producing and disseminating its pop culture products to various countries, even though its influence is profound. The popular culture of Ginseng Country is now known as Hallyu Wave or Korean Wave, or K-Pop (1). Korean wave or Hallyu is a term given to Korean pop culture or Korean wave. This Korean wave has affected various parts of the world, including Indonesia. In Indonesia, the Korean wave phenomenon is very influential, especially for young people or teenagers. In general, teenagers are very fond of Korean dramas or so-called drakor. In addition to drama shows that managed to make teenagers like it, several other factors such as music that is rampant today with the handsomeness of boy band and girl band members and music that makes the spirit start the days for us.

Other factors make teenagers like kpop from fashion, such as clothes, cosmetics, and what their idols wear (Nastiti, 2010) (4). The emergence of the Hallyu wave in Indonesia is inseparable from the liberalization and diversification of the media in Indonesia, which plays an essential role in the spread of Korean pop culture. The liberalization began in 1989, establishing five private TV stations in an Indonesian mediascape that had only one stateowned TV station, namely TVRI (Kitley, 2000) (1).

\section{East Javanese culture}

East Javanese culture is the result of a culture that originated and developed rapidly in East Java Province. The culture that developed in East Java is very diverse, with Javanese culture being the strongest influence. In addition, there is another Madurese culture (Madura island) and Osing culture in the horseshoe area (eastern and southeastern part of East Java), coloring the cultural dynamics in East Java (21). 
Other famous East Javanese arts include East Javanese style wayang kulit purwa, mastermind masks in Madura, and besutan. In the Mataraman area, Central Javanese arts such as ketoprak and wayang kulit are quite popular. Famous legends from East Java include Damarwulan and Angling Darma. Traditional dance art in East Java, in general, can be grouped into Central Javanese style, East Javanese style, Osing style Javanese Dance, and Madurese style trian. Classical dance arts include gambyong Dance, srimpi Dance, bondan Dance, and kelana. Remong Dance, a dance from Surabaya that symbolizes the soul, heroism. Danced at the time of welcoming guests. Reog Ponorogo, is an East Java regional dance that shows strength, masculinity, and valor (21).

For musical instruments, there are various types. The first is Angklung Caruk. Angklung Caruk is a musical instrument that comes from Banyuwangi, East Java. This musical instrument is usually played in a duel between groups or individuals; the way to duel is by answering each other to sound Angklung when the opponent has shown his abilities. One Angklung Caruk produces only one tone, so to produce a different tone Angklung Caruk must be played in a set of Angklung that has different tones and can be played in groups or individually (6). Angklung Reog is a musical instrument that originated from Ponorogo, East Java. According to its name, this musical instrument is played as an accompaniment in the staging of the art of Reog Ponorogo (6).

There is also a Bonang musical instrument. Bonang is a collection of gongs with a small size, and each has a different scale (6). There is also Kempul which is a musical instrument that is usually played at the Jaranan Sentherewe event. This musical instrument is made of brass and wood as a gathering place (6). Then there are various Kenong (Telok, Estri, Jaler), a gong (6).

For wind instruments, there is a name called Saronen. This musical instrument is made using teak wood given six holes in a row and one hole in the back, and there is a small ring made of metal to tie the bottom with the top made of siwalan leaves (6). In addition, there are also exceptional trumpets that are usually used to go with cultural events, such as Reog Ponorogo (6).

Tong-Tong musical instrument is a musical instrument that originated from Madura, East Java. In addition to Madura this musical instrument is also often found in other areas called Kentongan. Usually, this musical instrument is played during karapan sapi or sapi sono, 
although Tong-Tong is more often used to signal the public about a need, such as a disaster, gathering, waking up sahur, and other needs (6).

The shape of buildings in western East Java (such as in Ngawi, Madiun, Magetan, and Ponorogo) is generally similar to Central Java's shape (Surakarta). Typical buildings of East Java generally have the form of joglo, the form of limasan (dara gepak), the form of srontongan (empyak setangkep). The Dutch East Indies colonial period also left behind several ancient buildings. Cities in East Java have many buildings built in the colonial era, especially in Surabaya and Malang (21).

This East Javanese traditional dress is called mantenan. These clothes are often used during the marriage in East Java. Various excellent products from East Java form bamboo weaving crafts in caping, hats, trays, lampstands, tissue places, fruit places, newspaper places, and various souvenirs from another bamboo. The industrial center is located in Ringinagung Village +-1.5 southwest of Magetan city (21).

East Javanese people generally practice monogamous marriage. Before the proposal, the man performs a nako'ake event (asking if the girl already has a prospective husband), after which a peningsetan (application) is performed. A meeting or reunion precedes the wedding ceremony. To pray for the person who has died, usually, the family sends prayers on the 1st, 3rd, 7th, 40th, 100th, 1st year, and 3rd year after death (21).

In addition, there is another Milkfish Culture from Sidoarjo where the community shows the best results of the pond. Then, a Kasodho ceremony is owned by the Tengger tribe, where the event is held around Mount Bromo. The event was held as a form of gratitude to the surrounding community by pouring produce into the mountain crater (21).

Another art is Ludruk. Ludruk is one of the East Javanese arts that is quite famous, namely the stage art where all the players are generally male. Ludruj tells of the daily life of ordinary people, which is often spiced with humor and social criticism, and generally opens with the Remo Dance and parik (21).

There is also his name Reog. Reog is one of the cultural arts that comes from East Java, especially the city of Ponorogo. It is not only the lion's head mask that is a mandatory device of this art. Nevertheless, also the figure of warok and gemblak are part of Reog's art. In Indonesia, Reog is one of the regional cultures that is still very thick with things that smell of mysticism and mysticism (21). 
One type of culture from East Java, more precisely from the Madurese tribe, is Karapan sapi. Karapan sapi is a typical cattle race from the island of Madura. By pulling a carriage, two cows compete, accompanied by a Madurese gamelan called saronen. In this race, a pair of cows pulling a kind of wooden cart (where the jockey stands and controls the pair of cows) is driven in a quick duel against other pairs of cows (21).

\section{B. Early History of East Java Culture}

\section{Early Culture to the Kingdom}

The cultural history of East Java cannot be separated from the distribution of its ethnic groups. It is known that the majority of the population of East Java comes from the Javanese tribe. The emergence of the Javanese Tribe took a long journey. The Javanese tribe is the result of descent from the Deutro Melayu Culture. Deutero-Malay brought a more advanced culture than Proto-Malay culture. The arrival of Deutro-Malays to Indonesian territory could not be separated from them, pushing Proto-Malays into Indonesian territory. According to Sarasin's theory, Proto-Malay descendants were pushed into the interior by the arrival of new immigration, Deutero-Malays, who also came from the northern part of Indochina and the surrounding areas. Deutero-Melayu is identified as the person who introduced iron tools and weapons to the world of the Indonesian archipelago. The study of the development of civilization in Indochina seems to show the date for this event, that immigration occurred between 300 and 200 BC (Bernard Vlekke HM 2010: 10) (18). Almost all other people in Indonesia, except Papuans and surrounding islands, are included in the Deutero-Malay class (Bernard Vlekke HM 2010: 10) (18), including Javanese.

After some time, the East Java region was known to have not been controlled by the kingdom (living separately in groups). Finally, a small kingdom emerged called the Kanjuruhan kingdom. According to the Dinoyo inscription, which dates to 682 Saka (760 AD). This inscription was found split into three parts. The most significant middle section is found in Dinoyo Village, Malang. In contrast, the upper and lower parts are found in Merjosari Village and Kejuron Hamlet, Karangbesuki Village, Malang. "As far as it has been found, the Dinoyo inscription is the oldest inscription in the East Java region," said Dwi Cahyono, a history lecturer at the State University of Malang (22). 
From the inscription, it can be seen that the Kanjuruhan Kingdom was once established in the Malang area. In particular, this inscription reports that Gajayana saw that the Agastya statue made by his ancestors was rotten because it was made of sandalwood. Gajayana replaced it with a more elegant black stone. "Until now, not many people know that in East Java there is an old kingdom; they know that it was the Sindok, Airlangga, then Singhasari, and Majapahit times," Dwi (22) continued.

Although he does not have a long life, according to Dwi, it is enough reason to state that Kanjuruhan is the foundation stone and the shaping of an orderly socio-cultural system in Malang Raya. Furthermore, the kingdom and character of Kanjuruhan were the capital for the development of the center of the Singhasari Kingdom government to the center of the Majapahit vassal state. "The presence of the Kanjuruhan Kingdom has triggered the birth of urban areas in the Metro and Brantas valleys, which over time have become centers of government and civilization," said Dwi (22).

As explained before, after the appearance of the Kanjuruhan kingdom, there was a change in power to belong to the ancient Mataram kingdom. This was added by the move of his kingdom from Central Java to East Java. Then, many kingdoms began to appear in East Java, such as Kediri, Singhasari, and Majapahit. The question is, is there a relationship between these kingdoms and the culture in East Java? The answer is there. This is because each kingdom must carry its own culture so that this culture has developed from time to time to the present. Today's culture is a legacy that has existed for a long time, such as kris. Keris has been around since time immemorial and is used for various things. One famous kris is the keris made by Mpu Gandring, which was used as a deadly weapon during the Singosari kingdom because it is said to have great power.

\section{The Influence of Western Imperialism on Culture}

After passing through the kingdoms in Indonesia, especially in East Java, many other foreigners started to come. At first, they only wanted to do trade, but gradually their goal changed to 3G (Gold, Glory, Gospel), which means Gold (treasure), Glory (power), and Gospel (spread of religion in this case Christianity). In addition, there is also another spread through a culture known as Cultural Imperialism. 
Cultural imperialism is an effort to dominate other countries through cultures displayed to create superiority and domination of culture throughout the world through various means, starting from war, colonialism, and the media. Imperialism is inseparable from the history of western cultural colonialism. At first, colonialism in the world was carried out by western nations to control state land in the eastern region to control its spices in the motive of economic interests, but this shifted to political domination and colonization solely to safeguard trade interests against political turmoil-local, which can disrupt the smooth trade of the western nation (2).

Colonialism took place in three stages, starting from the Vasco da Gama era in 1498 to the industrial revolution in England in 1763, which saw the emergence of European powers such as Spain and Portugal, then post-industrial revolution until 1870, and the last one in 1914 when the peak of the World War occurred. I. Imperialism in control of colonies controls countries that are considered inferior and underdeveloped to exploit existing resources in the country to increase the wealth and power of the colonial State (2).

Imperialism is based on spreading western ideas and culture throughout the world as a driving force for reform aimed at developing a nation through education, health, the law, and government systems. Imperialism and colonialism in western societies left many cultural artifacts and non-artifacts, such as language, culture and deep into person and group attitudes. It is clear from this description that the west 'seems' to colonize the east for its sake. The most substantial reason is orientalism and imperialism (eastern ideology) in western society (2).

This makes cross-fit directly in the context of intercultural interaction and understanding. In imperialism, views of certain events, ideas, and people that occur can differ, causing prejudice against objects to become non-neutral. Interpretation of attitudes expressed differently triggers competition to discrimination between ethnicities, races, and cultures. Concerning colonial expansion, there is a particular interest in an area and population. The western group implies a view of the identity of westerners with power and power and views the eastern group as a weak part so that the western group has full authority over the eastern population (Machart et al., 2016) ). Western imperialism towards the east crosses literature, architecture, international relations, business, and trade (2).

The Dutch colonial presence in Indonesia, which became the ruler on the island of Java, also influenced the cultural aspects, which included seven elements, namely language, life equipment systems, livelihoods and economic systems, social systems, arts, science, and 
religious elements (Soekiman \& Juwita, 2011, p.4). One aspect of culture that has changed is the element of lifestyle in indigenous communities. Kartodirdjo (1999, p. 80) states that mixing the Dutch lifestyle with the lifestyle of the indigenous people, especially Javanese, can be called the Indis lifestyle (10).

Discussing about indist culture, it will be related to the people's lifestyle. One of the studies includes the model or style of clothing of the community. Clothing is used to cover parts of the human body, such as clothes, pants, skirts, etc. Clothing is vital and becomes a primary and secondary need for humans (Nurhajarini \& Soekiman, 2003). Clothing is a fundamental need for humans. Humans need clothes because clothes provide many functions and benefits in human life (10). The functions of clothing, according to Zaman (2002, p. 14), are as follows:

1. Clothing as protection for the human body. Clothing is used to protect the body from various negative influences on humans, for example, protection from dust, dirt, etc.

2. Helping activities or human work, for example, such as the use of diving clothes that can be used by humans for activities in the sea and so on

3. Clothing as a basic human need, Three basic needs that are basic human needs in Javanese teachings, namely clothing (clothing), food (eating), and board (residence)

4. Human jewelry, everyone can look attractive by wearing the right clothes plus accessories for clothing

5. Clothes can show human social status; clothes can usually show someone's identity, as seen from the model and the materials used (10).

So at that time, the point was the influence of cultural change by Western Imperialism on many things, including clothing.

\section{Globalization}

\section{Definition of Globalization}

Globalization comes from the English language "the globe" or French "La monde," which means earth or the world. So "globalization" or "mondialisation" is the process of making everything one earth or one world. Baylis and Smith define globalization as a process of increasing linkages between communities so that events that occur in certain areas affect human life or communities in other areas. Anthony Gidens calls globalization a "time-space 
distanciation", namely a world without borders; space and time are not significant constraints in conditions like this (17).

In another aspect, Wallerstain, a world system theory pioneer, views globalization as not limited to cross-border relations, but globalization is a form of world capitalist economic triumph which is driven by the logic of capital accumulation. Following Wallerstain, Jin Young Chung, a political scientist from Korea, defines globalization as a process of world integration through an increase in the flow of capital, products, services, ideas, and people across national borders (Machali, 2004, 109). Thus, globalization is a meeting of two interrelated historical processes, namely: first, globalization is a product of the dynamics of capitalist expansion and the unlimited accumulation of capital (capital/money). Second, globalization is a project produced or carried out by dominant social forces trying to institutionalize their power in a historic structure that will help the transitional capital expansion (Muslam 2011, 110) (17).

The main actors in the flow of globalization are developed countries. They seek to globalize their local values to become global values through the spread of globalization flows (Syarifah \& Kusuma, 2016). The flow of information and communication technology supports the spread or transformation of local values in developed countries to become global, considering that developed countries control information and communication technology. On the other hand, developing countries cannot compete with developed countries because they do not have a competitive value due to the lack of knowledge about information and communication technology. This results in people living in developing countries who become mere spectators (RD Nasution, 2017). The global values brought by developed countries are easy to develop in their destination countries (11).

\section{Impact of Globalization}

\section{a. Positive Impact}

Impact means millions of people/youth, one against another, one ethnic group against another, one nation against another. His cultural identity is increasingly visible. These positive impacts include the rapid spread of information in parts of the world, increasingly advanced technology, increasingly sophisticated internet online systems, the development of new knowledge, freedom of the press, increasing national economic growth, making it more accessible in terms of local/long-distance communication, increasing development, and making driving easier. (Fast to the destination), and the level of life for the better (13). 


\section{b. Negative impact}

A negative impact means, from the increasingly aggravating life and technology getting ahead and making it easier to gather information, causing our country to be entered by many cultures by developed countries. These negative impacts include, among others, shipments from foreign cultures that are not selected, modernization has eroded local culture, uncontrolled news media, unbalanced economic growth between the center and the regions, local human resources are not ready to accept new technology, rampant smuggling of goods into the country, abuse in technology (cybercrime) (13).

\section{Impact of Foreign Culture}

\section{Impact of Westernization}

\section{a. Positive Impact}

With Westernization, more and more cultural elements enter the community, one of the driving factors for social change in society. If it is done by running a good management system, the community will be able to make it a solution in overcoming social problems that occur, but this will damage the social order in society. In addition to being able to master science and technology (Science and Technology) from an idea and ideas, the occurrence of cultural acculturation so that it does not experience cultural boredom because people always want new things can follow fashion fashions and lifestyles that are currently popular, and the use of language- other languages in communication in increasing insight into science (8).

\section{b. Negative Impacts}

1. Westernization breeds secularization.

Secularization is alienating religion from social and State life. With this idea, society was prevented from involving the role and function of religion in regulating political affairs.

2. The loss of indigenous traditions and culture.

With the existence of Westernization, people serve foreign cultures more than their own culture. This can result in a decline in the morale of the population of a country that is affected by Westernization. For example, the night world makes the Indonesian people trapped in negative things and not following the ethics of the Indonesian State.

3. Social Order Threatened. 
Westernization in society will become a breakdown in the social order; different circumstances very much influence this condition in people's lives. Many unsuitable deviations will ultimately endanger social order.

4. Social interaction patterns change.

Westernization will also accelerate existing social interaction patterns. Social interaction will move in line with development and progress due to Westernization; thus, the norms and values that are carried out do not follow the nature of the Indonesian people's lives. (8), And so on.

\section{Impact of the Hallyu / Korean Wave}

\section{a. Positive Impact}

1. Kpop Becomes Inspiration in the World of Fashion

Many young people who have a great want to know Korean things, causing them to be inspired to imitate or imitate dressing and find out the fashion mix of the idols they admire (4).

2. Knowing

One's image Self-image is a picture that a person has of himself as a physical creation associated with physical characteristics in one's appearance in general or someone's thoughts about other people's views of himself and how people judge him (Wibowo, 2007). (4).

3. Can Socialize And Be Independent

With the existence of this kpop world, teenagers can be more creative in developing themselves. With their friendship, they have become friends from various regions, as well as from foreign countries, because fellow idol fans are admired, such as learning to be independent, brave enough to do business, such as opening an online shop selling kpop-related things such as clothes, cosmetics, and others. The advantages of selling online can make a person independent. It is said to socialize because with those who have the same character, admire the same idol, like the same drama so that a fast relationship is established based on fellow kpop fans (Hurlock, 2003) (4).

4. Can be motivated and enthusiastic 
People can be motivated because by admiring Korean things they will automatically want to learn to understand the Korean language to expand more fields of foreign language power. Moreover, music can also be used as motivation because it can increase enthusiasm for learning by listening to kpop music. Furthermore, the stories of their idols are also considered to be inspiring, which they pour out through their songs.

5. Emotional benefits can make fun, relieve stress for adolescents who are tired from homework or assignments from school (4).

\section{b. Negative Impact}

1. Excessive fan attitudes (4).

2. occurs towards these adolescents

Fanaticism is a very phenomenon in modern times, the personal social reality of society because at this time it affects an individual to create trust and understanding in the form of devotion, relationship, loyalty, love (Seregina, Koivisto \& Mattila, 2011) (4).

3. An attitude of imitation of an exaggerated self-image arises.

The influence of Korean drama shows that attract the public's attention, especially teenagers, causes imitation. This is evidenced by the existence of a lifestyle and collecting things that smell of K-pop and the imitation of the physical appearance of the image of his life (Kaparang, 2013). With this imitation so that the teenager will imitate in such a way, especially for women. They will follow fashion by wearing clothes that are not suitable to wear. It contrasts our country, which mostly adheres to the Islāmic religion (Tartila, 2013 (4).

\section{Conformity}

Conformity is certain behavior that is carried out due to the influence of another person or group to carry out the same behavior and actions. Or do not like what he is doing (Sears, Freedman, \& Peplau, 1994). Conformity is not only in behavior and actions that are influenced by others, but the person also acts and thinks differently from what he does if he is alone (Myers , 2012) (4)

5. Wasting time and money on pointless things 
Sometimes teenagers nowadays forget about the time they have wasted because they are complacent about the want to see their idols, causing forgetting to study, forgetting to take a break because of watching Korean dramas, and wasting money for buying things that are not useful and sometimes tend to buy excessive internet quota just for stalking his idol (4).

6. Eye health because often look at cell phone (4).

7. Insomnia or difficulty sleeping because some people stay up late too often just for the marathon watching the drama. This is, of course, very time-consuming for the person to rest (4).

8. Sometimes, the effect of kpop culture also affects children in dressing, especially for women who want to imitate what clothes are worn by their idols. Sometimes they wear very disrespectful clothes, which is very contrary to religion, especially in Indonesia, which Islam dominates. For this reason, parents need attention to supervise and control their children (4).

\section{E. The Importance of an Almost Forgotten Cultural Restoration}

From the two impacts before described, the negative impacts tend to be stronger than the positive ones. The two examples of culture should be limited and return to the original culture of Indonesia, especially for the people of East Java, namely the original culture of East Java. Before turning to East Java Province, it would be better to discuss it on a national scale first.

Culture is one of the assets owned by the Indonesian nation. In the past, heroes fought and conferred with the invaders. They negotiate to decide the boundaries of Indonesian territory. The result is the territory of Indonesia as depicted on the map of Indonesia today. Of course, the territory is a territory and includes all the wealth in it (9). Territory and all the wealth we must defend and protect because there lies the sovereignty of our country. We must not allow it to be taken or taken by foreigners or people. The task of safeguarding all of this is indeed left to the State. However, as citizens, we must also protect it (9). The point does not let an original Indonesian culture, especially East Javanese culture, disappear in a cultural context. It would be pleasant for a nation's generation to keep up its sustainability.

Besides that, learning history is also significant. Learning history will develop the activities of students to study various events, then be understood and internalized to themselves to give birth to examples of behavior and action. Among these events, there are messages 
related to heroic values such as exemplary, willingness to sacrifice, love for the country, togetherness, independence, equality, nationalism, and patriotism (9).

In history lessons, many subjects or topics contain these historical values. For example, when discussing the colonial period, it is very proper to re-actualize identity and individual or human rights, human values, nationalism, and patriotism (9).

Returning to East Java, here is a data index for cultural growth in Indonesia in 2018.

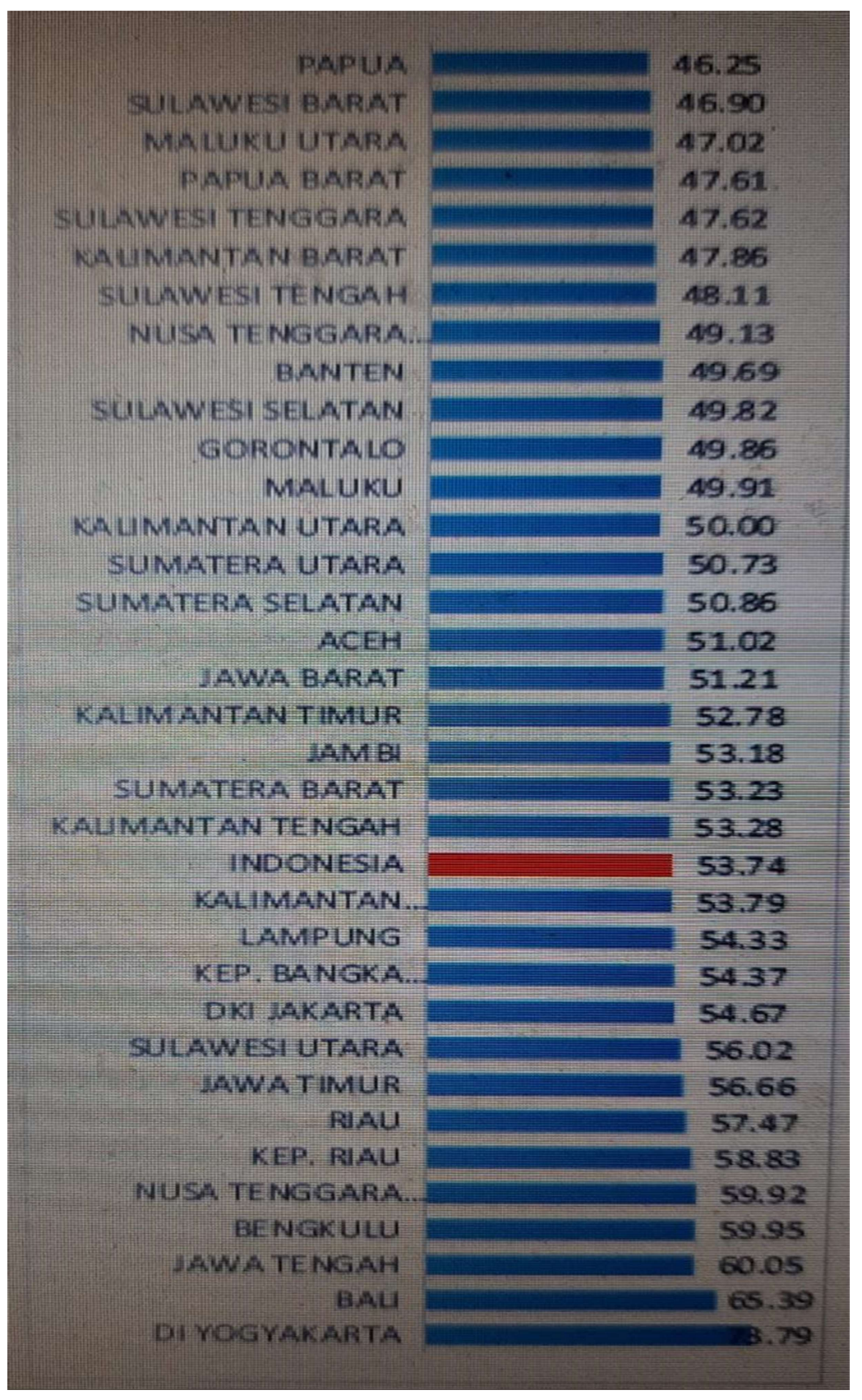

Figure 1. Indonesian Cultural Growth Index by the province in 2018 (12) 
Judging from the data above, the more significant the index value, the greater the cultural growth. DI Yogyakarta, Bali, and Central Java are in the top three positions. This proves that in areas such as DI Yogyakarta and Bali, they still keep up local culture and historical buildings but keep abreast of existing developments (Permata, 2016; Soeroso and Susilo, 2008; Miharja, 2013; Suwardani, 2015) (12).

East Java occupies 8th place out of all provinces in Indonesia with an index of 56.66 (above the average Indonesian index reaching 53.74 according to data). These results are indeed good. However, if some people look at the further development of culture, especially in big cities of East Java such as Surabaya, Malang, Sidoarjo, and other areas related to modern culture, then the index may decline. Therefore, it is necessary to preserve the culture of East Java during the massive development of modern culture.

One of the goals of holding cultural preservation is also to carry out cultural revitalization (strengthening). There are three steps to cultural revitalization: 1 . understanding to raise awareness, 2. collaborative planning, and 3. generating cultural creativity. (Alwasilah, 2006: 18). Sustainability cannot stand alone because it is always coupled with development, in this case, survival. Sustainability is an aspect of stabilizing human life, while survival is a reflection of dynamics. (Soekanto, 2003: 423) (15).

It is a provision in cultural preservation for the existence of a cultural form, which means that the preserved culture is still there and is known, even though its development is increasingly eroded or forgotten. This preservation can only be done effectively if the preserved objects are still used and are still being carried out. When that culture is no longer used, that culture will disappear. When the community no longer uses the tools, the tools will automatically disappear (15).

Maintaining and preserving Indonesian culture can be done in various ways. There are two ways that people can do, especially as the younger generation, in supporting cultural preservation and participating in preserving local culture (Sendjaja, 1994: 286). namely:

\section{Culture Experience}

Culture Experience It is cultural preservation that is carried out by plunging directly into a cultural experience. For example, if the culture is in the form of a dance, then people are encouraged to learn and practice mastering the Dance, and it can be performed annually at specific events or the holding of festivals. Thus the local culture can always be preserved (19). 
2. Culture Knowledge

Culture Knowledge is preserving culture, which creates an information center about the culture that can be fictionalized into many forms. The aim is for education and the benefit of cultural development itself, and the potential for regional tourism. Thus, the Young Generation can enrich their knowledge of their own culture. Apart from being preserved in the two forms above, local culture can also be preserved by getting to know its culture. Thus, at least we can expect cultural piracy committed by other countries. The problem that often occurs in society is that sometimes they do not feel proud of their products or culture. We are more proud of imported cultures that are not following the nation's personality as an Eastern person. The era of local culture is starting to disappear because people, especially the younger generation, lack the awareness to preserve it. As a result, we only have a voice when other countries are successful and famous, with the culture they take secretly. Therefore, the role of government in preserving the nation's culture is also significant. However, the government has a big role in preserving the local culture in the country (19).

The government must carry out policies that lead to efforts to preserve national culture. One of the government policies that deserve to be supported is the appearance of regional cultures at every major national event, such as dances, regional songs and sarong performances, etc. More concretely, recently, President Joko Widodo has obliged all his staff to have all important national events such as the Indonesian Independence Day on August 17 each year to wear their respective traditional clothes based on their region of origin. This needs to be appreciated because it is an effort to preserve Indonesian culture. All of this is done to introduce local culture to the younger generation, that the culture displayed is a legacy from their ancestors, not from neighboring countries, as well as efforts through formal education channels (Ranjabar: 2006: 34) (19).

The public is obliged to understand and know the various kinds of culture they have. The government can also focus more on the education of local content of regional culture. Apart from the things mentioned above, there are still other ways to preserve local culture (Yunus: 2014: 123), namely:

a. Improve the quality of human resources in advancing local culture.

b. Encourage the community to maximize the potential of local culture and its empowerment and preservation. 
c. Trying to revive the spirit of tolerance, kinship, hospitality, and high solidarity.

d. Always maintain Indonesian culture so that it does not become extinct. Strive for the community to be able to manage local cultural diversity (19).

Indonesian culture is a culture that the Indonesian people only own, and each regional culture has its characteristics. The Indonesian nation also has a very rich and diverse local culture. Therefore, as the next generation, we are obliged to protect it because the existence and resilience of local culture are in the younger generation, and we should not be lulled into, let alone fall into a foreign culture because not all foreign cultures are following the personality of the Indonesian people, even many foreign cultures have a negative impact. As an archipelagic country, it must be challenging to keep up unity and integrity between the people. However, this can be minimized if we have concern and awareness to protect, study, and keep, so that the local culture, which is very rich in Indonesia, remains intact and does not become extinct, let alone hijacked or stolen by other countries because culture is the identity of a nation and State. (19).

Especially for the East Java region, this region is rich in various cultures. Many East Javanese cultures claimed by other countries, such as Reog, which was claimed to be a dance from Malaysia, a typical Ponorogo art that has been patented since 2001, reog is now also an icon of East Java art (21). Do not let an incident like that happen again.

\section{F. Examples of Cultural Preservation in East Java}

There are many ways of preserving culture in East Java, but the author takes 3 examples that exist and can be applied in East Java with 2 examples discussing regional languages and 1 example discussing a cultural school. From this example, it is hoped that other people can take the positive side of preserving East Javanese culture. Even though East Java's context, other people who do not come from East Java can imitate it according to their respective cultures in their place.

\section{Learning Game-Based to Improve Javanese Script Reading and Writing Skills}

A problem that concerns researchers is the lack of government attention to Javanese culture. Takano (2011) reveals that Javanese culture is currently not being paid attention to by the government and the Indonesian people. This is caused by several things, one of which is the existence of increasingly new technology so that people are more busy playing with gadgets than learning Indonesian culture, such as Javanese script. Moreover, parents now want their 
children to follow the modern era. So many Indonesian children, especially native Javanese today, do not understand or even know anything about Javanese script. With the waning of Javanese culture, especially Javanese character in society (7).

This research was conducted from April to August 2019. This research lasted for approximately 5 months and was conducted at the Al-Maun Orphanage, located on Jalan Margo Noyo, Ngajum Village, Ngajum District, Malang Regency, East Java Province, Indonesia. The Al-Maun Orphanage is inhabited by caregivers and orphans, with the number of children living in the Al-Maun orphanage is around 18 people (7).

The sequence of implementing the teaching activities that researchers did:

a). Purchasing Equipment and Materials

b). Making Teaching Syllabus

c). Making Evaluation Questions

d). Find Educational Movies and Games

e). Introduction to Javanese Script

f). Teaching Javanese script

g). Teaching Javanese script through games

h). Understanding Material Evaluation Tests

i). Evaluating Teaching Method (7)

From the research, according to the author, at least we can instill the culture of one of the cultures of East Java, namely the Javanese language. This culture is packaged in a game to help teach from an early age or for people who hardly ever learn and use Javanese.

\section{Preservation of Javanese Culture by the Tunggulwulung Cultural School in Malang City, East Java}

There are various things done at SBT in an effort to preserve Javanese culture. Some of them are ngangsu kawruh or conducting studies on cultural history and heritage arts (especially Javanese culture), mocopatan or macapat development, martial arts, dances, and mbulan padhang. Padhang mbulan activities are carried out once a month, on the 15 th in the Javanese calendar, as a form of expression of gratitude to God Almighty. Apart from these 
routine activities, many other activities are also carried out to learn about the culture in Tunggulwulung Village, such as learning to be MC and learning to dance. All of these activities have their respective teachers or trainers who are experts in their fields. There is something else that is no less interesting and unique, namely the hodgepodge of cultural activities at the school. This is called a hodgepodge of cultures because all participants or students who join SBT will be taught all the arts. Especially the arts in Java (11).

The methods that SBT uses to preserve Javanese culture are by providing facilities or access to study culture and arts at the Cultural School. There is no cost to study and join in a place to learn about Javanese culture, all for free. So that people are free to come, study, and join the school. Through this method, it is hoped that the community will be interested and have the enthusiasm to take part in learning and preserving. In addition, the school also introduces the general public to ancestral culture and arts through training, studies, and performances, which are held every Sunday. For the sustainability of SBT, it is hoped that the cultural school can be developed into a foundation so that it can be balanced. Through the concept of a foundation, it is also hoped that it can support the development and sustainability of the Cultural School in Tunggulwulung Village. So that later this place to learn about Javanese culture can develop like private schools in general (11).

With the introduction of SBT to a wide audience, the space for self-actualization for participants and cultural activists in the cultural school has also become more comprehensive. They are invited to participate in various performances at various events, especially arts and cultural events. Through good performances and performances, dedication, and contributions from cultural activists in preserving culture (especially Javanese culture), the school received appreciation from the East Java Province Tourism and Culture Office in 2017. The appreciation was given to the Tunggulwulung Cultural School for the artist class achievers in cultural development (11). The Tunggulwulung Budayan School or SBT can be an example of a form of cultural preservation during the development of modern culture.

\section{Personal Habits Against the Javanese Language}

This begins with the existence of public knowledge of its role in Javanese culture. The community must have an important role in preserving their culture. People in Java also have to play a role in preserving Javanese culture, one of which is the language. The development of Javanese culture will further develop the Javanese language. As long as the Javanese people still live and continue to speak Javanese, Javanese culture will continue to develop, and its 
development will affect the development of the Javanese language or vice versa. (Sartini, 2009) (14)

In the younger generation in school life, many of them feel bored and bored with the material being taught. This is because the teachers are too monotonous in teaching Javanese subjects. Therefore, teachers need to change the way of teaching Javanese subjects different things, such as after the modern era today. Teachers can use electronic learning media such as computers, laptops, VCD / DVD, gadgets, and other electronic media, and do not forget the use of the internet as a means of finding detailed information. In this way, students become more aware of the material presented in Javanese subjects. Then the students became interested in Javanese and began to get used to speaking Javanese, so that indirectly the community, especially students, had preserved one of Javanese culture, namely Javanese language (14). Learning Javanese and other cultures must be instilled in anyone from an early age to be more accustomed to it in the future. Starting from small things like this, although quite difficult. However, over time this habit will get better. Not only Javanese but Javanese culture, especially East Java, can be preserved in ways like this.

\section{CONCLUSION}

Culture is familiar to all levels of society in this world. Culture will constantly develop along with the development of information and technology in this modern era. Culture is permanently attached to everyday life. Culture varies because every country, province, and even city has its own culture. This argues that culture is the inheritance of the ancestors of civilization with their respective characteristics and through special symbols that have different thoughts. As explained earlier, cultures are diverse. The cultures that have the most significant influence in the world are western culture and South Korean culture. Both cultures have had a significant impact, especially in Indonesia.

This culture is always carried by the flow of globalization from one region to the world. So, every person from a place can use that culture. It is undeniable that this incident had a positive impact. Apart from being a result of technology, this event provides complete knowledge and relationships between people. However, this positive impact is not offset by the negative impact. 
One of the negative impacts of this incident is the lack of interest in the community, especially the younger generation, in their native culture, especially for the East Java region. They began to leave their cultural heritage and prefer to follow the modern culture. If this continues to be done, the culture of East Java may disappear without remaining because no one has preserved it.

East Java is a province that has excellent cultural potential that is diverse and unique. Examples of East Java Culture are Regional Languages, Reog, Ludruk, various musical instruments, cow races, dances, and other cultures which are very diverse. This argues that East Java has heterogeneous communities such as the Madurese, Osing, "Arek" Javanese, "Kulonan" Javanese, Tengger, and so on. History records that this region has had much cultural influence, even for centuries. Starting from the Deutro Malay Age, the Age of the HinduBuddhist Kingdom, to the time of Western Imperialism by Colonialism. This gives rise to the wealth of this region.

Actually, the way to solve this problem is not difficult. Starting from the smallest things first, such as knowing the culture of each individual's origin. Then, slowly learn like language. After that, just learned other things. Over time, everyone will get used to the culture of origin, in this case East Java. With the initiation of steps like these, other societies will automatically follow the culture and restore the culture from an almost lost identity.

For research limits, researchers only limit the culture of the province of East Java, not in general throughout Indonesia. For foreign cultures, only 2 cultures are taken, namely Western Culture and South Korean Culture (Hallyu) among so many cultures in this world. The results obtained are more for solutions and pilot applications in everyday life.

The research from this paper is very useful to explain things about the importance of culture in East Java when the impact of cultural globalization is great, especially about Western culture and South Korean Culture (Hallyu). The explanation of this paper starts from basic things such as understanding and description and then describes it in its entirety. 


\section{BIBLIOGRAPHY}

1. Cara M. “MENJADI KOREA ”: BAGI REMAJA DI SURABAYA. 2020;7-19.

2. Yudipratomo O. Benturan Imperialisme Budaya Barat Dan Budaya Timur Dalam Media Sosial. J Audience. 2020;3(2):170-86.

3. Budiarto G. Dampak Cultural Invasion terhadap Kebudayaan Lokal: Studi Kasus Terhadap Bahasa Daerah. Pamator J. 2020;13(2):183-93.

4. Putri LA, Islam U, Sultan N, Kasim S, Info A. DAMPAK KOREA WAVE TERHADAP PRILAKU REMAJA. 2020;3(1):42-8.

5. Ramadhani AF, Nuranib F. Mempertahankan Kebudayaan Dan Persatuan Bangsa Dengan Humanisme. BlogUbAcId [Internet]. 2019; Available from: http://blog.ub.ac.id/annidaramadhani/files/2019/12/Annida-Fadilatul-Ramadhani-2.pdf

6. Isi D. Mengenal Berbagai Macam Alat Musik Jawa Timur Alat Musik Jawa Timur Alat Musik Tradisional Jawa Timur. 2019;

7. Fatima WQ, Khairunisa L, Prihatminingtyas B. METODE PEMBELAJARAN BERBASIS GAME UNTUK MENINGKATKAN KETRAMPILAN MEMBACA DAN MENULIS AKSARA JAWA. 2020;3(1):17-22.

8. Clooney G. Moderenisasi dan Westernisasi. 2019;1-21.

9. Nafsar HM, Sma Negeri G, Gowa PK, Selatan S. NKRI Harga Mati: Penanaman Nasionalisme dan Patriotisme Melalui Pendidikan Karakter Berbasis Sejarah Kearifan Budaya Lokal. Pendidik dan Penelit Kesejarahan. 2020;7(2):200.

10. Press AIN. PAKAIAN SEBAGAI SIMBOL STRATIFIKASI SOSIAL MASYARAKAT JAWA PADA MASA KOLONIAL ABAD KE-19 SAMPAI AWAL ABAD KE-20. 2020;1(1):157-74.

11. Pebrianto M, Hadi N. Pelestarian Budaya Jawa Oleh Sekolah Budaya Tunggulwulung di Kota Malang, Jawa Timur. J Educ Hum Soc Sci. 2021;3(3):879-87.

12. Zuriatina I. Pengaruh Pembangunan Kebudayaan Terhadap Pembangunan Manusia Di Indonesia. TEMALI J Pembang Sos. 2020;3(1):1-17.

13. Januarharyono Y. Peran Pemuda Di Era Globalisasi. J Ilm Magister Adm. 2020; 
14. Piesa CP. Peran Pendidikan Bahasa Jawa dalam Pelestarian Budaya Jawa. 2020;

15. Khalda RA, Nurani F. Peran Tanggung Jawab dan Kesadaran Masyarakat Indonesia Terhadap Budayanya dalam Era Globalisasi. 2019;

16. Yuhasnil. Perubahan Nilai Budaya dalam Arus Modernisasi Di Indonesia. J Penelit dan Kaji Ilmu [Internet]. 2019;13(5):222-30. Available from:

https://jurnal.umsb.ac.id/index.php/menarailmu/article/view/1397

17. Dewi E. Potret Pendidikan di Era Globalisasi Teknosentrisme dan Proses Dehumanisasi. Sukma J Pendidik. 2019;3(1):93-116.

18. Setiawan J, Ida Permatasari W. Proses Masuk dan Persebaran Peninggalan Kebudayaan Proto-Deutero Melayu di Indonesia. Fajar Hist J Ilmu Sej dan Pendidik. 2019;3(1):11-22.

19. Nahak HM. Upaya Melestarikan Budaya Indonesia Di Era Globalisasi. J Sosiol Nusant. 2019;5(1):65-76.

20. Tuna-sejarah WTDAN. Wacana tuna-budaya dan tuna-sejarah pada generasi masa kini. 2019;15(2):98-107.

21. Redaksi. Ragam Kesenian dan Budaya di Jawa Timur [Internet]. Jybmedia. 2020 [cited 16 Mei 2021]. Available from: https://jybmedia.com/2020/07/11/ragam-kesenian-danbudaya-di-jawa-timur/

22. Risa HP. Kerajaan Tertua di Jawa Timur [Internet]. historia. 16 Jan 2019 [cited 24 Mei and 26 Mei 2021]. Available from: https://historia.id/kuno/articles/kerajaan-tertua-di-jawatimur-DnwAq/page/1

23. Umar S, Mohamad MC. Metode Penelitian Kualitatif di Bidang Pendidikan. Ponorogo: Nata Karya; 2019.

24. Zed M. Metode Penelitian Kepustakaan. Jakarta: Yayasan Obor Indonesia; 2008. 


\section{ATTACHMENT}

Table 1. Summary of Results from Journal Articles

\begin{tabular}{|c|c|c|c|}
\hline $\begin{array}{c}\text { Author / Researcher } \\
\text { (Year) }\end{array}$ & $\begin{array}{l}\text { Research } \\
\text { methods }\end{array}$ & Title & Result \\
\hline Cara M. (2020) & Quantitative & $\begin{array}{l}\text { Becoming Korean "Seeing } \\
\text { the Ways, Forms and } \\
\text { Meanings of Korean Pop } \\
\text { Culture for Youth in } \\
\text { Surabaya }\end{array}$ & $\begin{array}{l}\text { Contains data about } \\
\text { South Korean culture } \\
\text { (Hallyu) and begins } \\
\text { with the impact of } \\
\text { Western (Western) } \\
\text { culture. }\end{array}$ \\
\hline $\begin{array}{l}\text { O. Yudipratomo } \\
(2020)\end{array}$ & $\begin{array}{l}\text { Literatur } \\
\text { Review }\end{array}$ & $\begin{array}{l}\text { The Clash of Western } \\
\text { Cultural Imperialism and } \\
\text { Eastern Culture in Social } \\
\text { Media }\end{array}$ & $\begin{array}{l}\text { Contains data about the } \\
\text { differences between } \\
\text { Western and Eastern } \\
\text { imperialism and their } \\
\text { relationship in social } \\
\text { media }\end{array}$ \\
\hline G. Budiarto & Qual & $\begin{array}{l}\text { Impact of Cultural Invasion } \\
\text { on Culture } \\
\text { Local: Case Studies on } \\
\text { Local Languages }\end{array}$ & $\begin{array}{l}\text { Contains data about the } \\
\text { impact of the cultural } \\
\text { invasion in Local } \\
\text { Languages. But the } \\
\text { researchers only took } \\
\text { the cultural } \\
\text { understanding } \\
\text { according } \\
\text { Soekmono. }\end{array}$ \\
\hline Putri L. A. (2020) & $\begin{array}{l}\text { Literatur } \\
\text { Review }\end{array}$ & $\begin{array}{l}\text { The Impact of the Korean } \\
\text { Wave on Youth Behavior } \\
\text { in the Age of Globalization }\end{array}$ & $\begin{array}{l}\text { Contains data about } \\
\text { Korean Wave Sundries } \\
\text { and its positive and } \\
\text { negative impacts. }\end{array}$ \\
\hline $\begin{array}{l}\text { Annida Fadilatul } \\
\text { Ramadhani (2019) }\end{array}$ & $\begin{array}{l}\text { Literatur } \\
\text { Review }\end{array}$ & $\begin{array}{l}\text { Maintaining Culture And } \\
\text { National Unity With } \\
\text { Humanism }\end{array}$ & $\begin{array}{lr}\text { Contains } & \text { about } \\
\text { maintaining } & \text { culture } \\
\text { with } \quad \text { humanism. }\end{array}$ \\
\hline
\end{tabular}




\begin{tabular}{|c|c|c|c|}
\hline & & & $\begin{array}{l}\text { However, the author } \\
\text { only uses the meaning } \\
\text { of culture according to } \\
\text { Koentjaraningrat }\end{array}$ \\
\hline Isi D. (2019) & $\begin{array}{l}\text { Qualitative } \\
\text { Descriptive }\end{array}$ & $\begin{array}{l}\text { Get to know the various } \\
\text { kinds of East Java musical } \\
\text { instruments }\end{array}$ & $\begin{array}{l}\text { Contains a variety of } \\
\text { musical instruments } \\
\text { typical of East Java. }\end{array}$ \\
\hline Fatima W. Q. (2020) & Quantitative & 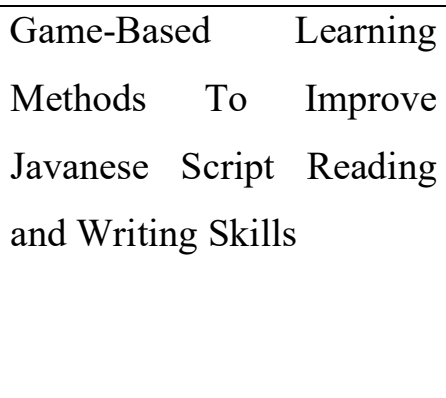 & $\begin{array}{l}\text { Contains research on } \\
\text { Javanese reading and } \\
\text { writing skills for } \\
\text { children at the Al-Maun } \\
\text { Orphanage, Malang, } \\
\text { East Java }\end{array}$ \\
\hline Clooney G. (2019) & $\begin{array}{l}\text { Qualitative } \\
\text { Descriptive }\end{array}$ & $\begin{array}{l}\text { Modernization and } \\
\text { Westernization }\end{array}$ & $\begin{array}{l}\text { Contains } \\
\text { modernization and } \\
\text { Westernization } \\
\text { sundries. The majority } \\
\text { of researchers here take } \\
\text { things about } \\
\text { Westernization }\end{array}$ \\
\hline Nafsar H. M. (2020) & $\begin{array}{l}\text { Literatur } \\
\text { Review }\end{array}$ & $\begin{array}{l}\text { NKRI Harga Mati: } \\
\text { Cultivating Nationalism } \\
\text { and Patriotism through } \\
\text { Historical-Based Character } \\
\text { Education of Local } \\
\text { Cultural Wisdom }\end{array}$ & $\begin{array}{l}\text { Discusses the } \\
\text { inculcation of a sense of } \\
\text { nationalism through } \\
\text { character education } \\
\text { based on the history of } \\
\text { social cultural wisdom. } \\
\text { In this case, it can be } \\
\text { interpreted as the } \\
\text { importance of culture } \\
\text { for the Indonesian } \\
\text { people, especially in the } \\
\text { East Java Region. }\end{array}$ \\
\hline
\end{tabular}




\begin{tabular}{|c|c|c|c|}
\hline $\begin{array}{l}\text { Nursela Yunika } \\
\text { Mesita (2020) }\end{array}$ & $\begin{array}{l}\text { Literatur } \\
\text { Review }\end{array}$ & $\begin{array}{l}\text { Clothing as a symbol of } \\
\text { social stratification of } \\
\text { Javanese society during the } \\
\text { colonial period of the } 19 \text { th } \\
\text { century to the beginning of } \\
\text { the 20th century }\end{array}$ & $\begin{array}{l}\text { Contains a depiction of } \\
\text { the condition of } \\
\text { Javanese society in that } \\
\text { year which has } \\
\text { differences depending } \\
\text { on social strata. }\end{array}$ \\
\hline Pebrianto M. (2021) & Qualitative & $\begin{array}{l}\text { Preservation of Javanese } \\
\text { Culture by the School of } \\
\text { Culture } \\
\text { Tunggulwulung in Malang } \\
\text { City, East Java }\end{array}$ & $\begin{array}{l}\text { Contains } \\
\text { Tunggulwulung } \\
\text { Culture School (SBT) } \\
\text { in Malang, East Java } \\
\text { and its development in } \\
\text { culture }\end{array}$ \\
\hline Isna Zuriatina (2020) & Quar & $\begin{array}{l}\text { The Influence of Cultural } \\
\text { Development on Human } \\
\text { Development in Indonesia }\end{array}$ & $\begin{array}{l}\text { Contains index of } \\
\text { cultural development in } \\
\text { Indonesia }\end{array}$ \\
\hline $\begin{array}{l}\text { Januarharyono } \mathrm{Y} . \\
(2020)\end{array}$ & $\begin{array}{l}\text { Literatur } \\
\text { Review }\end{array}$ & $\begin{array}{l}\text { The Role of Youth in the } \\
\text { Globalization Era }\end{array}$ & $\begin{array}{l}\text { Contains sundries about } \\
\text { globalization and the } \\
\text { role of youth in these } \\
\text { events }\end{array}$ \\
\hline Piesa C. P. (2020) & $\begin{array}{l}\text { Qualitative } \\
\text { Descriptive }\end{array}$ & $\begin{array}{l}\text { The Role of Javanese } \\
\text { Language Education in the } \\
\text { Preservation of Javanese } \\
\text { Culture }\end{array}$ & $\begin{array}{l}\text { Contains the } \\
\text { importance of the } \\
\text { Javanese language for } \\
\text { people in Java so that } \\
\text { they can preserve one } \\
\text { of the original Javanese } \\
\text { cultures. }\end{array}$ \\
\hline Khalda R.A. (2019) & $\begin{array}{l}\text { Literatur } \\
\text { Review }\end{array}$ & $\begin{array}{l}\text { The Role of Responsibility } \\
\text { and Awareness of } \\
\text { Indonesian Society for Its } \\
\text { Culture in the Era of } \\
\text { Globalization }\end{array}$ & $\begin{array}{l}\text { Contains the role of } \\
\text { society in culture in the } \\
\text { Globalization Era. } \\
\text { However, researchers } \\
\text { used data about cultural } \\
\text { preservation goals }\end{array}$ \\
\hline
\end{tabular}




\begin{tabular}{|c|c|c|c|}
\hline Yuhasnil (2019) & $\begin{array}{l}\text { Literatur } \\
\text { Review }\end{array}$ & $\begin{array}{l}\text { Changes in Cultural Values } \\
\text { in the Process of } \\
\text { Modernization } \\
\text { Indonesia }\end{array}$ & $\begin{array}{l}\text { Contains changes in } \\
\text { cultural values in } \\
\text { Indonesia. However, } \\
\text { researchers used data } \\
\text { about the classification } \\
\text { of cultural forms } \\
\text { according to } \\
\text { Koentjaraningrat. }\end{array}$ \\
\hline Dewi E. (2019) & $\begin{array}{l}\text { Literatur } \\
\text { Review }\end{array}$ & $\begin{array}{l}\text { Portrait of Education in the } \\
\text { Era of Globalization, } \\
\text { Techno centrism and the } \\
\text { Dehumanization Process }\end{array}$ & $\begin{array}{l}\text { Contains the process of } \\
\text { education in the era of } \\
\text { globalization }\end{array}$ \\
\hline Setiawan J (2019) & $\begin{array}{l}\text { Historical } \\
\text { research }\end{array}$ & $\begin{array}{l}\text { Entry Process and } \\
\text { Distribution of Cultural } \\
\text { Heritage } \\
\text { Proto-Deutero Malay in } \\
\text { Indonesia }\end{array}$ & $\begin{array}{l}\text { Contains the entry of } \\
\text { this Prehistoric Proto- } \\
\text { Deutro Malay } \\
\text { generation in Indonesia. } \\
\text { Researchers take from } \\
\text { the Deutero Malay side } \\
\text { as the origin of the } \\
\text { Javanese Tribe }\end{array}$ \\
\hline Nahak H. M. (2019) & $\begin{array}{l}\text { Qualitative } \\
\text { Descriptive }\end{array}$ & $\begin{array}{l}\text { Efforts to Preserve } \\
\text { Indonesian Culture in the } \\
\text { Era of Globalization }\end{array}$ & $\begin{array}{l}\text { Contains steps in } \\
\text { preserving Indonesian } \\
\text { culture in the } \\
\text { development of } \\
\text { globalization and the } \\
\text { entry of foreign culture }\end{array}$ \\
\hline $\begin{array}{l}\text { Tuna Sejarah } \\
\text { WTDAN (2019) }\end{array}$ & $\begin{array}{l}\text { Historical } \\
\text { research }\end{array}$ & $\begin{array}{l}\text { Discourse on Culture- } \\
\text { Themes and Deaf-History } \\
\text { in the Present Generation }\end{array}$ & $\begin{array}{l}\text { Contains discourses on } \\
\text { cultural themes and } \\
\text { historical disabilities } \\
\text { that endanger the } \\
\text { nation's future } \\
\text { generations. However, } \\
\text { researchers use a }\end{array}$ \\
\hline
\end{tabular}




\begin{tabular}{|l|l|l|l|}
\hline & & & $\begin{array}{l}\text { general understanding } \\
\text { of culture. }\end{array}$ \\
\hline Redaksi (2020) & $\begin{array}{l}\text { Qualitative } \\
\text { Descriptive }\end{array}$ & $\begin{array}{l}\text { Variety of Arts and Culture } \\
\text { in East Java }\end{array}$ & $\begin{array}{l}\text { Contains discussion of } \\
\text { various from East } \\
\text { originating from } \\
\text { Java }\end{array}$ \\
\hline Risa H.P. (2019) & $\begin{array}{l}\text { Literatur } \\
\text { Review }\end{array}$ & $\begin{array}{l}\text { The oldest kingdom in East } \\
\text { Java }\end{array}$ & $\begin{array}{l}\text { Contains a discussion } \\
\text { of the history of the } \\
\text { Kanjuruhan kingdom } \\
\text { which is considered the } \\
\text { first kingdom in East } \\
\text { Java. }\end{array}$ \\
\hline $\begin{array}{l}\text { Umar S, Mohamad } \\
\text { MC (2019) }\end{array}$ & $\begin{array}{l}\text { Literatur } \\
\text { Review }\end{array}$ & $\begin{array}{l}\text { Qualitative } \\
\text { Methods in the Field of } \\
\text { Education }\end{array}$ & $\begin{array}{l}\text { Reventains the steps or } \\
\text { methods of qualitative } \\
\text { research in the field of } \\
\text { education }\end{array}$ \\
\hline Zed (2008) & Library Research Methods & $\begin{array}{l}\text { Contains methods of } \\
\text { research and literature }\end{array}$ \\
\hline
\end{tabular}

